\title{
Regulatory Consent Decrees: An Argument for Deference to Agency Interpretations
}

\author{
Phillip G. Oldham $\dagger$
}

Consent decrees are essentially contracts between litigants that courts enter as judgments to settle litigation. As judgments, consent decrees have preemption and enforcement effects that reach beyond ordinary settlement agreements, yet courts interpret them as simple settlement contracts. But what happens when an administrative agency enters into a consent decree to enforce a public welfare statute such as the Clean Water Act? Should the "agreement" still be understood as a simple contract, with future interpretations depending solely on a court's interpretation of the wording of the agreement, or do the decree's effects on third parties and the public at large change its character? This Comment argues that they do. New understandings of administrative law mandate a rethinking of how courts interpret regulatory consent decrees.

Traditionally, judicial review of administrative actions squared nicely with courts' authority to interpret contracts. Courts had the final say. The question of who should make policy, however, was and is central to the relationship between courts and administrative agencies. In a normative sense, courts prior to Chevron U.S.A. Inc. v Natural Resources Defense Council, Inc. ${ }^{1}$ were much more concerned with "supervising" agency choices. ${ }^{2}$ In a post-Chevron world, courts should recognize that their role is more limited. ${ }^{3}$ Chevron's explicit recognition that statutory interpretation involves significant policy choices has changed the legal landscape. Properly understood, Cheuron dissolved the distinctions between law and policy; and, although still important, the question of who should interpret a document is now decided less on comparative expertise in legal interpreta-

$\dagger$ B.A. 1992, University of Texas at Austin; J.D. Candidate 1995, The University of Chicago.

1467 US 837 (1984).

2 Kenneth W. Starr, Judicial Review in the Post-Chevron Era, 3 Yale J Reg 283, 30001 (1986).

3 Id. 
tion, and more upon democratic notions about who should make policy. ${ }^{4}$

Into this new understanding of agency-court relationships comes increasing agency reliance on consent decrees not only as a means of settling lawsuits but also as a regulatory tool. ${ }^{5}$ When agencies rely on consent decrees to enforce statutes, subsequent interpretations of these often-ambiguous decrees have important policy implications. ${ }^{6}$ The application of contract law to the interpretation of consent decrees may fail to take into account the public policy concerns specific to the regulatory state. It may also increase litigation and hamper effective regulation as private parties try to avoid statutory duties by litigating over ambiguities in the decree. ${ }^{7}$

This Comment argues that the fundamental shift in the relationship between courts and agencies, embodied in Cheuron, should encompass consent decree interpretation. Chevron stands for the notion that, without specific guidance from Congress, courts should not interfere with reasonable agency policy choices-the type of choices often involved in interpreting regula-

4 Cass R. Sunstein, Law and Administration after Chevron, 90 Colum L Rev 2071, 2086 (1990). See also Laurence H. Silberman, Chevron-The Intersection of Law \& Policy, 58 Geo Wash L Rev 821, 823 (1990).

5 Agencies often use consent decree settlements as a method of statutory enforcement. See Thomas M. Mengler, Consent Decree Paradigms: Models Without Meaning, 29 BC L Rev 291, 328, 331 (1988) (referring to consent decrees as "law enforcement tools"). See also Maimon Schwarzchild, Public Law by Private Bargain: Title VII Consent Decrees and the Fairness of Negotiated Institutional Reform, 1984 Duke L J 887, 888; Jeffery G. Miller, Private Enforcement of Federal Pollution Control Laws Part II, 14 Envir L Rep 10063, 10080 (1984). Note that this Comment only deals with the situation where an agency chooses to enforce a statute by entering into a consent decree, and does not concern itself with situations where a consent decree results from a citizen's suit to force agency action. For a discussion of the latter, see Jeremy A. Rabkin and Neal E. Devins, Averting Government by Consent Decree: Constitutional Limits on the Enforcement of Settlements with the Federal Government, 40 Stan L Rev 203 (1987); Note, Separation of Powers and the Reagan Administration's Policy on Consent Decrees: Have the Courts Overstepped the Limits of Judicial Powers?, 1989 U $\mathrm{Ml}$ L Rev 541; Larry Kramer, Consent Decrees and the Rights of Third Parties, 87 Mich L Rev 321 (1988).

6 Although interpreting consent decrees as contracts may pose little difficulty in the private party context, it is problematic in the enforcement of public laws where agencies use decrees to carry out their statutory mandates. In this context, the contract model ignores the far-reaching policy implications of court interpretations as well as the agencies' interests in the efficient enforcement of our public laws. See text accompanying notes 61-66. See also New York State Ass'n For Retarded Children, Inc. $v$ Carey, 596 F2d 27, 37 (2d Cir 1979); Lloyd C. Anderson, The Approval and Interpretation of Consent Decrees in Civil Rights Class Action Litigation, 1983 U Ill L Rev 579, 616.

7 See text accompanying notes 108-09. See also Mengler, 29 BC L Rev at 329 (noting that ambiguities may be intentionally inserted into a consent decree as a part of the bargain or to delay enforcement). 
tory consent decrees. Just as Chevron exploded the idea that courts are best situated to interpret statutes, it should also revolutionize the interpretation of consent decrees. Consent decrees in the regulatory realm often involve broader policy concerns than private contracts. In interpreting these agreements, courts must either ignore policy concerns or make forward-looking judgments about which reading best achieves the decree's statutory purposes. ${ }^{8}$ The public welfare aspect of interpreting these agreements suggests that neither of these situations is desirable. Under a proper reading of Chevron, interpretation should be left to agencies in which Congress has vested regulatory authority. Both comparative expertise and political accountability counsel for this division of labor. ${ }^{9}$

Part I of this Comment looks at how Cheuron fundamentally changed the way courts view agency interpretation of statutes and how that thinking has affected areas beyond statutory interpretation. Part II lays out the general law of consent decrees in all its confusion and shows the unsatisfactory results of applying current doctrine in regulatory cases. Part III, recognizing the policy determinations inherent in interpreting consent decrees, proposes a stylized Cheuron test for consent decree interpretation. It also discusses arguments in favor of this deference proposition and attempts to defuse the concern that parties will no longer enter into these agreements if agency interpretations receive deference. This Comment concludes that a Chevron-type deference would lead to more effective regulation and greater efficiency in the adjudication of consent decree disputes. More importantly, this change in interpretation would lead courts to respect agency choices, and place regulatory policy back into the appropriate hands.

${ }^{8}$ See text accompanying notes 85-96.

9 Agencies, even independent agencies, are typically viewed as more democratically responsive than the courts. See Sunstein, 90 Colum L Rev at 2087-88 n 80 (cited in note 4) ("TThe democratic pedigree of the agency is usually superior to that of the court."); Silberman, 58 Geo Wash L Rev at 823-24 (cited in note 4). See also Jerry L. Mashaw, Prodelegation: Why Administrators Should Make Political Decisions, 1 J L Econ \& Org 81, 95-99 (1985) (arguing that agencies and the executive are actually more democratic than Congress); Michael A. Fitts, Retaining the Rule of Law in a Chevron World, 66 Chi Kent L Rev 355, 356-57 (1990) (asserting that agencies are "under the informal control of either a democratically elected Congress or President"). 


\section{CHEVRON: DEVELOPMENT AND APPLICATIONS}

Historically, the fundamental debate among administrative law scholars has been how to maintain the "rule of law" in the face of agency policy-making discretion. ${ }^{10}$ Traditional common law notions guided the early period in administrative law, dividing the authority of courts and agencies along the lines of law and fact-similar to the roles played by judge (law) and jury (fact). ${ }^{11}$ Questions of law, such as the interpretation of statutes, were for judges, while questions of fact or policy were to be decided by the agencies. This analysis comported nicely with the understanding in Marbury $v$ Madison that "it is emphatically the province and duty of the judicial department to say what the law is." ${ }^{12}$ However, the line between law and policy in administrative law is blurry, and making distinctions between the two proved difficult. ${ }^{13}$ In Chevron, the Court recognized this difficulty and, marking a doctrinal break from the past, endorsed a distinct view of the proper relationship between courts and agencies. $^{14}$

10 See Fitts, 66 Chi Kent L Rev at 356 (cited in note 9). See also Maureen B. Callahan, Must Federal Courts Defer to Agency Interpretations of Statutes?: A New Doctrinal Basis for Chevron U.S.A. v. Natural Resources Defense Council, 1991 Wis L Rev 1275, 1278-79.

${ }^{11}$ Thomas W. Merrill, Judicial Deference to Executive Precedent, 101 Yale L J 969, 994 (1992).

125 US (1 Cranch) 137, 177 (1803). See also Panel Discussion, Judicial Review of Administrative Action in a Conservative Era, 39 Admin L Rev 353, 361 (1987) (Kenneth W. Starr speaking); Starr, 3 Yale J Reg at 283, 293 (cited in note 2).

${ }_{13}$ See Panel Discussion, 39 Admin L Rev at 357-61 (Kenneth W. Starr speaking). See also Sunstein, 90 Colum L Rev at 2082 (cited in note 4); Note, A Framework for Judicial Review of an Agency's Statutory Interpretation: Chevron, U.S.A., Inc. v. Natural Resources Defense Council, 1985 Duke L J 469, 471; Silberman, 58 Geo Wash L Rev at 823 (cited in note 4); Merrill, 101 Yale $L J$ at 994-95 (explaining that the law/fact paradigm lasted up until the enactment of the Administrative Procedure Act and, until Cheuron, a multifactored contextual approach was used).

${ }^{14}$ See Sunstein, 90 Colum L Rev at 2087 (cited in note 4). See also Richard J. Pierce, Jr., Chevron and its Aftermath: Judicial Review of Agency Interpretations of Statutory Provisions, 41 Vand L Rev 301, 302 (1988); Starr, 3 Yale J Reg at 284 (cited in note 2). Cheuron has proved to be an extremely influential case. Between 1984 and 1990, the case was cited over one thousand times. Sunstein, 90 Colum L Rev at 2074-75 (cited in note 4). On the effects of Chevron generally, see Peter H. Schuck and E. Donald Elliott, To the Chevron Station: An Empirical Study of Federal Administrative Law, 1990 Duke L J 984. Debate continues over the decision's applicability to areas of the law beyond statutory interpretation. Some scholars argue that Cheuron embodied a general proposition about deference to agency policy-making, and as such was not limited simply to questions of statutory interpretation. For a discussion of this position see Callahan, 1991 Wis L Rev at 1286-89. 


\section{A. Facts of Cheuron}

The Cheuron case mirrors the interpretive problem in many consent decree cases: the documents at hand-whether they are statutes, legislative history, or consent decrees-simply do not provide a ready answer to the question litigated. Chevron involved EPA's redefinition of the term "source" in the Clean Air Act to allow greater permit flexibility by pollution-producing plants. ${ }^{15}$ The D.C. Circuit held that the statute did not warrant this change in definition. Although the statute was silent on the proper definition of "source" and the legislative history did not squarely address the issue, the court held that EPA's new definition was inconsistent with the purpose of the permit program-to improve air quality. ${ }^{16}$

The Supreme Court, however, reversed the D.C. Circuit, holding that the court had made a mistake in adopting a static definition of "source" when Congress had not defined the term that way, and that the court had usurped the agency's authority to define "source" at its discretion. ${ }^{17}$ The language and legislative history of the Clean Air Act gave no guidance as to the proper reading of the word "source." In such instances, the Court held, it is inappropriate for a reviewing court to decide which reading best comports with the aim of the statute. That job belongs to the agency. ${ }^{18}$

\section{B. The Two-Part Test}

Chevron requires courts to defer to an agency's interpretation of a statute so long as that interpretation does not violate the statute's plain meaning and is a reasonable reading of silence or ambiguity in the statute. ${ }^{19}$ Chevron set forth a two-part analysis with which to evaluate any agency action involving a question of

15467 US at 840 . Prior to 1980 , "source" had been defined as any pollution-emitting device in a plant. Thus, if a plant had more than one pollution emitter, modifying any one of them required a permit. In 1981, however, EPA changed its definition of "source" and established the "bubble" concept. Under this definition, a new pollution emitter could be added or an existing one altered without a permit, as long as the change did not increase the plant's total pollution output. Id.

16 National Resource Defense Council, Inc. $v$ Gorsuch, 685 F2d 718, 720-23 (DC Cir 1982). Note that this problem often arises in consent decree cases: when crafting an agreement, parties either never consider the contingency at issue or are unclear about their views.

17 Chevron, 467 US at 863-64.

18 Id at 865-66.

19 Id at 842-44. See also Mississippi Power \& Light Co. v Moore, 487 US 354, 380 (1988) (Scalia concurring); Sunstein, 90 Colum L Rev at 2074 (cited in note 4). 
statutory interpretation. The first question is whether Congress gave its view on the issue. If congressional intent is clear, then courts and the agency are bound to obey Congress. ${ }^{20}$ If, however, the statute and legislative history are silent on the issue, then courts must assume that Congress intended to delegate discretion to decide the issue to the agency. Courts may only overrule the agency's interpretation if it is "arbitrary, capricious, or manifestly contrary to the statute."21

\section{The Rationale of Cheuron}

Chevron was based on respect for Congress's decision to vest regulatory authority in administrative agencies and a desire to limit judicial policy-making inherent in the interpretation of statutes. As the Court noted, agencies are institutionally superior to courts as policymakers because courts lack the political accountability and expertise of administrative agencies. ${ }^{22}$ Thus, as long as an agency acts within its statutory authority, it is better situated to decide these issues. ${ }^{23}$

Certain assumptions about the proper roles of courts and administrative agencies underlie the Chevron decision. ${ }^{24}$ Regulation inevitably requires a certain amount of policy-making discretion. This need stems from the difficulties that arise during the normal course of regulating. Congress cannot possibly antici-

$20 \quad 467$ US at $842-43$.

21 Id at 843-44. In determining this,

[t]he court need not conclude that the agency construction was the only one it permissibly could have adopted to uphold the construction, or even the reading the court would have reached if the question initially had arisen in a judicial proceeding.

Id at $843 \mathrm{n}$ 11. Commentators have likened this standard to arbitrary-and-capricious review under the Administrative Procedure Act. See Sunstein, 90 Colum L Rev at 2105 (cited in note 4).

${ }^{22} 467$ US at 865 . Here policy must be understood by reference to those instances where political accountability and expertise are most relevant. This is different than policy as it is made by courts in adjudicating disputes because, in this instance, Congress has empowered an agency with the authority to make national policy over an area of regulation. By doing so, Congress has spoken on who should make policy on, say, the environment. Although courts may properly decide the adequacy of such a system under our Constitution, it is not the province of the courts to "legislate" environmental policy. That power belongs to EPA, which must make decisions about how to allocate resources or how best to protect the environment.

${ }^{23}$ Id at 865-66.

24 Pauley $v$ United States Department of Labor, 501 US 680, 696 (1991) ("Judicial deference to an agency's interpretation of ambiguous provisions of the statutes it is authorized to implement reflects a sensitivity to the proper roles of the political and judicial branches."), citing Cheuron, 467 US at 866. 
pate all the contingencies inherent in the regulation of a complex industry or area of law, but this should not result in a grant of policy-making discretion to the judiciary. Chevron mandates the assumption that Congress has given agencies the discretion to make appropriate policy choices in order to serve their public function. ${ }^{25}$ Thus, unless Congress clearly states its intention to have courts substantively review agency policy decisions, the courts' role should only be to "check" and not to supervise or dictate. ${ }^{26}$

\section{Generalizing Chevron: Its Logic beyond Statutory Interpretation}

The Chevron rationale is not necessarily limited to statutory interpretation. Indeed, the institutional advantages of agencies apply to a broad range of administrative activities. Recognizing this, courts have applied Cheuron to other areas where broad policy implications have been found in traditionally "legal" tasks.

1. Applying Chevron to contract interpretation.

Traditionally, courts viewed interpretation of industry contracts as a purely legal endeavor; thus, they reviewed agency interpretations of contracts de novo. ${ }^{27}$ Some courts, however, have recently applied the principles of Cheuron to contract interpretation, holding that it is sufficiently similar to statutory interpretation to warrant deference-especially when the interpreta-

${ }^{25}$ Sunstein, 90 Colum L Rev at 2084 (cited in note 4).

${ }^{26}$ See Starr, 3 Yale $J$ Reg at 300-01 (cited in note 2). Some commentators have argued that Cheuron deference is constitutionally mandated by the separation-of-powers doctrine. Callahan, 1991 Wis L Rev at 1286-89 (cited in note 10) (surveying and discussing this view). Justice Scalia, however, has persuasively rejected this position, arguing that it is a prudential (yet fictive) reconstruction of congressional ambiguity that mandates Chevron deference. Antonin Scalia, Judicial Deference to Administrative Interpretations of Law, 1989 Duke L J 511, 514-18. This Comment allies itself with Justice Scalia insofar as Scalia focuses on the institutional advantages of agencies over courts and not on actual congressional intent. In other words, because Chevron involved a prudential fiction about congressional intent, this Comment focuses on the same legitimacy and expertise concerns as justifications for deference in the context of consent decree interpretation. As was the case in Chevron, courts should impute this intent to Congress in the absence of explicit evidence to the contrary because it comports more closely with our conception of what Congress ought to have intended or likely did intend.

${ }_{27}$ See Boston Edison Co. v Federal Energy Regulatory Comm'n, 856 F2d 361, 363-64 (1st Cir 1988) (declining to choose between de novo review and deference to the agency's interpretation); Texas Gas Transmission Corp. $v$ Shell Oil Co., 363 US 263, 268-70 (1960) (upholding de novo review of the agency's interpretation of the contract). 
tion involves a policy determination within the agency's statutory domain. $^{28}$

As the D.C. Circuit has indicated, the main difference between contract interpretation and statutory interpretation is that the former involves the wishes of private individuals. ${ }^{29}$ The involvement of private rights, however, should not limit the influence of Cheuron in this area. Statutory interpretations often affect private interests, indicting conduct made in reliance on previous interpretations. The D.C. Circuit has noted that:

[T] he holding in Cheuron rests not on the identities of the individuals whose intentions are in question, but on the fact that the governing statute explicitly or implicitly embodied Congress' decision to delegate authority to an agency over particular matters, thus compelling deference from the courts in reviewing how the agency exercised its authority on those matters. ${ }^{30}$

A reconstruction of congressional intent and an understanding of the proper role of courts in the regulatory scheme should guide the discussion concerning consent decrees. The implication of private rights should not override these considerations. Cheuron itself seems to contemplate putting agency policy choices above the reliance interests of those regulated. ${ }^{31}$ The application of Chevron to contract cases indicates its ability to reform concep-

${ }_{28}^{28}$ National Fuel Gas Supply Corp. v Federal Energy Regulatory Comm'n, 811 F2d 1563, 1570 (DC Cir 1987). See also Consolidated Gas Supply Corp. v Federal Energy Regulatory Comm'n, 745 F2d 281, 291 (4th Cir 1984); Amoco Production Co. v Federal Energy Regulatory Comm'n, 765 F2d 686, 690 (7th Cir 1985); Southern California Edison Co. v Federal Energy Regulatory Comm'n, 805 F2d 1068, 1072 (DC Cir 1986).

${ }^{29}$ National Fuel, 811 F2d at 1570 n 3.

${ }^{30}$ Id. This case dealt specifically with a settlement contract between two private parties. The D.C. Circuit, supported by some literature, raises the possibility of limiting Cheuron to those instances where the agency is not a party or where there is no danger of "self dealing." See id at 1571; Sunstein, 90 Colum L Rev at 2097, 2101 (cited in note 4) (discussing judicial deference to agency interpretations of jurisdiction and "agency bias" generally). This Comment rejects this as an unreasonable limitation on Cheuron, arguing instead that to have meaning, Chevron must apply in cases where the agency, in some sense, is ruling on its own case. Indeed, any time an agency interprets a statute it has a duty to enforce, the agency is self-dealing. See Mississippi Power \& Light Co. $v$ Moore, 487 US 354, 380-82 (1988) (Scalia concurring). In addition, specific safeguards exist in the regulatory consent decree context that may minimize the effects of agency bias. See generally Part III.

${ }^{31}$ Starr, 3 Yale J Reg at 300 (cited in note 2). Even though a party may have acted in reliance on a previous interpretation of a statute, her right to consistency should not override an agency's political choice. 
tions of certain legal arrangements-even a court's role in interpreting the sacrosanct contract.

2. Martin: Interpretation of agency regulations.

In Martin v Occupational Safety and Health Review Commission, the Supreme Court faced conflicting interpretations of a regulation promulgated by the Secretary of Labor under the Occupational Safety and Health Act ("OSHA"). ${ }^{32}$ The Secretary had issued a citation to an employer for violating a regulation. The employer appealed to the Occupational Safety and Health Review Commission ("OSHRC")— the group responsible for adjudicating disputes concerning OSHA regulations-which vacated the citation. ${ }^{33}$ The question in Martin was whether OSHRC (the adjudicator) or the Secretary (the policymaker) should receive deference in interpreting OSHA regulations. ${ }^{34}$

Repeating much of the reasoning in Chevron, the Martin Court stated that the agency must have authoritative power to interpret its own regulations because application of agency regulations to "complex" and "changing circumstances" requires "unique expertise" and determinations of "policy making prerogatives." ${ }^{.35}$ Accordingly, the Court held that the Secretary's interpretations of the OSHA regulations should receive deference because the Secretary has greater policy-making authority and regulatory expertise than OSHRC.$^{36}$ As the Court put it,

[a]lthough the Act does not expressly address the issue, we now infer from the structure and history of the statute... that the power to render authoritative interpretations of OSH Act regulations is a "necessary adjunct" of the Secretary's powers to promulgate and to enforce national health and safety standards. ${ }^{37}$

Although never citing Cheuron, the Martin Court clearly utilized Cheuron's analytical framework, ${ }^{38}$ and held that adjudicators

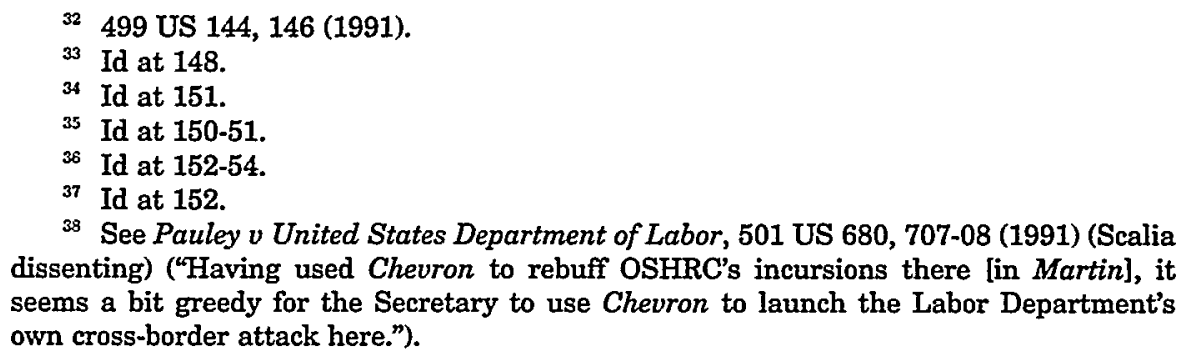

38 See Pauley v United States Department of Labor, 501 US 680, 707-08 (1991) (Scalia dissenting) ("Having used Chevron to rebuff OSHRC's incursions there [in Martin], it seems a bit greedy for the Secretary to use Chevron to launch the Labor Department's own cross-border attack here."). 
should defer to interpretations by those who have policy-making authorization, better political accountability, and greater expertise in their regulatory area. ${ }^{39}$

In other situations where legal interpretations involve significant policy issues, courts should apply the rationale of Chevron. Indeed, courts should prefer an agency's interpretations to their own whenever these interpretations involve regulatory policy within the agency's statutory authority. ${ }^{40}$ This understanding recognizes that agencies are institutionally better situated to make policy determinations. Because agency enforcement by consent decree may also involve policy concerns, ${ }^{41}$ the Chevron rationale should also apply in that context.

\section{CONSENT Decree InTerpretation: Confused Precedent AND MISAPPLICATION}

\section{A. Interpreting Consent Decrees as Contracts}

The most obvious problem with interpreting regulatory consent decrees as contracts is that reconstructing an agreement may not provide a satisfactory answer to the litigated question. While this may be acceptable in interpreting private agreements, favoring one plausible interpretation over another in the regulatory context may have broad policy implications that fetter agency discretion. As cases have illustrated, the lack of clarity in consent decree law exacerbates this problem. Current law leaves courts faced with differing interpretations largely in the dark. As one commentator has warned, Supreme Court precedent can be used to justify almost any interpretive norm. ${ }^{42}$

In United States v Armour \& Co., the Supreme Court laid out the "four cormers" rule for interpreting consent decrees. ${ }^{43}$ Armour treated consent decrees like contracts and implied that

39499 US at $152-53$.

10 See Starr, 3 Yale J Reg at 312 (cited in note 2); Silberman, 58 Geo Wash L Rev at 822-23 (cited in note 4); Pierce, 41 Vand L Rev at 303-04 (cited in note ?).

${ }^{41}$ See Peter M. Shane, Federal Policy Making By Consent Decree: An Analysis of Agency and Judicial Discretion, 1987 U Chi Legal F 241, 241-42.

${ }_{42}$ See Mengler, 29 BC L Rev at 299-300 (cited in note 5) ("No one serious about defining a district court's task in interpreting a consent decree should look to the Supreme Court for guidance. Because its stated view on interpretation has shifted with the merits of each case, the Court has charted all the possibilities and fixed its sights on none of them.").

402 US 673 (1971). 
courts should construe them as such. ${ }^{44}$ In an oft-quoted section of the opinion, the Court stated that:

Naturally, the agreement reached normally embodies a compromise; in exchange for the savings of cost and elimination of risk, the parties each give up something they might have won had they proceeded with the litigation. Thus the decree itself cannot be said to have a purpose; rather the parties have purposes, generally opposed to each other, and the resultant decree embodies as much of those opposing purposes as the respective parties have the bargaining power and skill to achieve. For these reasons, the scope of a consent decree must be discerned within its four corners, and not by reference to what might satisfy the purposes of one of the parties to it. ${ }^{45}$

The Court's unwillingness to use external evidence to interpret consent decrees stems from the adversarial nature of the agreement. Because litigation was the impetus for the agreement, it is likely that the interests of the two sides to the agreement were directly opposed to each other when they entered into the consent decree. Using this reasoning, the Court held that courts should rarely depart from the specific language of the decree for fear that post hoc interpretations will favor one party over the other. $^{46}$

However, in United States v ITT Continental Baking Co., the Court backed away from the strong language of Armour and used extrinsic evidence to interpret a consent decree that was not clear on its face. ${ }^{47}$ In Continental Baking, the United States sued a baking company for violating a consent decree that the company had entered into to settle antitrust violations. ${ }^{48}$ The decree prohibited the company from "acquiring" other bakeries for a specified period of time. ${ }^{49}$ The central question of the case was whether the term "acquiring" referred to a single act subject to a one-time penalty or permitted daily penalties for continuing to hold and operate the bakeries that the consent decree prohibited ITT from buying. ${ }^{50}$ To answer this question, the Court allowed

\footnotetext{
4 Id at 681-82.

45 Id.

46 Id at 682.

47420 US 223, 238 (1975).

48 Id at 227-29.

49 Id at 227-28.

so Id at 225.
} 
evidence concerning the "circumstances surrounding" the formation of the decree and found that a narrow reading of the word "acquiring" was inconsistent with the purposes behind the Clayton Act, one of the circumstances surrounding formation of the decree. Accordingly, the Court held that the agreement permitted ongoing daily penalties. The opinion, however, limited the use of extrinsic evidence sharply, stating that the evidence introduced could not depart from the "four corners" rule of Armour. ${ }^{51}$ In a move that seems to contradict an earlier part of the opinion that allowed courts to consider the purposes behind the Clayton Act in interpreting consent decrees, the Court stated explicitly that courts should not construe consent decrees in light of the legislation the government "sought to enforce but never proved applicable through litigation." "52 The Court explained this by saying that courts were not free to change the wording of a consent decree simply to further the government's statutory purposes. ${ }^{53}$

In a strong dissent, Justice Stewart noted that regardless of its qualifying language, the Court had opened the door to judicial construction in light of the "antecedent complaint," the "meaning" of statutory language, and the "underlying policies" the agency was attempting to enforce. ${ }^{54}$ Stewart maintained that such judicial interpretation would subvert the plain language of decrees because it would permit parties to argue for the incorporation of terms for which they did not bargain. This type of interpretation, Stewart argued, runs counter to the "plain language" standard of Armour. ${ }^{55}$ As Stewart predicted, subsequent courts have considered evidence that ranges far outside the "four corners" of the document. $^{56}$

51 Id at 238-43.

52 Id at 236-37.

53 Id at 235-36.

54 Id at 248-49 (Stewart dissenting) ("Before straining to pull the Government's chestnuts out of the fire, the Court should count with greater care the costs of abandoning the rule stated in Armour.").

s5 Id at 249-50.

s6 See City of Las Vegas v Clark County, 755 F2d 697, 702 (9th Cir 1985) (construing consent decree in light of the statute that agency originally sought to enforce); United States v Motor Vehicle Manufacturers Ass'n, 643 F2d 644, 650 (9th Cir 1981) (stating that courts should construe consent decree according to the purpose of the statute that decree is intended to enforce); United States $v$ Louisville and Jefferson County Metro Sewer District, 983 F2d 1070 (table), 1993 US App LEXIS 855, *16-17 (6th Cir) (construing consent decree according to the public interest in compliance with the Clean Water Act). See also Mengler, 29 BC L Rev at 301-03 (cited in note 5) (referring to Continental Baking as paying "lip service to Armour" while leaving the earlier case "in its wake"); Note, Substantive Standards and NEPA: Mitigating Environmental Consequences with Consent Decrees, 
Stewart's prophecy of unbridled confusion has become a reality as courts have inconsistently applied Armour and Continental Baking in a variety of settings. ${ }^{57}$ This is not surprising given the lack of coherent guidance by the Supreme Court, which has itself cited the rule of one without acknowledging the other. ${ }^{58}$ This confusion has exacerbated the problems of applying the contract model in the regulatory setting. Although it is not very troublesome for courts to exercise discretion in interpreting consent decrees of private litigants, extending that discretion in the regulatory context impinges upon authority that properly belongs to an administrative agency. Cheuron requires a different result: when Congress has not spoken clearly to the contrary, courts should prefer an agency's policy choices, even as expressed through interpretation of an agreement.

Continental Baking itself provides support for this proposition. Although Continental Baking was nominally about the use of extrinsic evidence to interpret a decree, the Court was clearly influenced by the purposes of the Clayton Act ${ }^{59}$ in reaching its conclusion. $^{60}$ In a post-Chevron world, the decision of which reading best comports with the goals of federal antitrust policy should be viewed as a question best left to agency interpretation.

\section{B. Interpreting Regulatory Consent Decrees: Courts as Policymakers}

Interpreting consent decrees in the administrative context differs markedly from interpreting decrees between private litigants. ${ }^{61}$ These differences stem from the statutory authorizations given to administrative agencies, ${ }^{62}$ public concerns for effi-

18 BC Envir Aff L Rev 159, 170 (1990) ("Regardless of the justification, the Court readily adopted a broader interpretation of the decree to conform to statutory objectives.").

${ }_{57}$ Mengler, 29 BC L Rev at 304-05 (cited in note 5).

cs See Firefighters $v$ Stotts, 467 US 561, 574 (1984). See also Mengler, 29. BC L Rev at 304 (cited in note 5) (noting that Stotts "returns to the language and spirit of Armour" but does not criticize Continental Baking).

59 Clayton Antitrust Act, Pub L No 63-212, 38 Stat 730 (1914), codified at 15 USC \$§ 12-27 (1988 \& Supp 1992).

w 420 US at 237.

${ }^{61}$ See United States $v$ Louisville and Jefferson County Metro Sewer District, 983 F2d 1070 (table), 1993 US App LEXIS 855, *16-17 (6th Cir), citing Heath $v$ DeCourcy, 888 F2d 1105,1109 (6th Cir 1989) ( ${ }^{\circ}$ Consent decrees which regulate institutional conduct are fundamentally different from consent decrees between private parties... The decrees reach beyond the parties involved directly in the suit and impact on the public's right to the sound and efficient operation of its institutions."); United States v O'Rourke, 943 F2d 180, 188 (2d Cir 1991); Navarro-Ayala v Hernandez-Colon, 951 F2d 1325, 1337-38 (1st Cir 1991).

${ }^{62}$ Before a court can enter a consent decree, it must find that the decree will "further 
cient administration, ${ }^{63}$ possible effects on third parties not involved in the decrees, ${ }^{64}$ and the comparative expertise of agencies in making policy decisions. ${ }^{65}$ Indeed, to properly balance these concerns, courts must make sensitive judgments on issues that may be fundamental to an administrative scheme. For instance, some courts have held that a court must interpret a regulatory consent decree in light of the requirements of the statute under which the agency sued. ${ }^{66}$ This rule of construction draws consent decree interpretation close to the Cheuron standard because both approaches require a reading of the statute at issue and will often require a judgment about which policy choice best comports with the statutory goals. In contrast, if a court does not take into account the statute under which the agency acted, important policy objectives may be ignored. Thus, under the contract model of interpretation, courts will either ignore the important policy implications of their decisions or make policy decisions that properly belong to an agency.

In entering and monitoring regulatory consent decrees, judges have become much more than mere interpreters of settlement contracts. One commentator has remarked upon the increasingly proactive role of judges interpreting regulatory decrees:

[1]n actively shaping and monitoring the decree, mediating between the parties, developing his own sources of expertise and information, the trial judge has passed beyond even the role of legislator and has become a policy planner and manager. ${ }^{67}$

the objectives of the law upon which the complaint was based." Firefighters $v$ Cleveland, 478 US 501, 525 (1985), citing EEOC v Safeway Stores, Inc., 611 F2d 795, 799 (10th Cir 1979). See also Citizens for a Better Environment $v$ Gorsuch, 718 F2d 1117, 1125, 1128 (DC Cir 1983).

${ }_{63}$ See Louisville and Jefferson County Metro Sewer District, 1993 US App LEXIS 855 at $* 16-17$.

${ }_{64}$ See Robert V. Percival, The Bounds of Consent: Consent Decrees, Settlements and Federal Environmental Policy Making, 1987 U Chi Legal F 327, 348.

${ }^{65}$ See text accompanying notes 22-41.

${ }^{66}$ See City of Las Vegas $v$ Clark County, 755 F2d 697, 702 (9th Cir 1985); United States v Motor Vehicle Manufacturers Ass'n, 643 F2d 644, 650 (9th Cir 1981); Louisville and Jefferson County Metro Sewer District, 1993 US App LEXIS 855 at *16-17.

${ }^{67}$ Abram Chayes, The Role of the Judge in Public Law Litigation, 89 Harv L Rev 1281, 1302 (1976). The Continental Baking decision is a good example of the types of decisions that judges must make under the current regime: do ongoing penalties best serve federal antitrust policy? See text accompanying notes 59-60. 
One has to wonder whether Congress intended agencies to be able to delegate such broad policy-making authority to the judiciary merely by entering into an agreement with a private party. ${ }^{68}$ The following Section demonstrates the gravity of attributing that understanding to Congress.

1. The possible breadth of regulatory consent decrees.

In 1982, the United States District Court for the District of Columbia entered a consent decree settling an antitrust suit between the United States Department of Justice ("Justice De-. partment") and AT\&T. ${ }^{69}$ The consent decree attempts to foster competition by requiring AT\&T to provide companies other than the regional Bell Operating Companies ("BOCs") equal access to the interexchange and information services markets, and by imposing limitations on the entry of BOCs into other nonregulated markets where they might have monopolistic tendencies. $^{70}$

There is little doubt that the D.C. District Court has been significantly involved in setting regulatory policy through the consent decree. The goal of the decree is to foster competition. ${ }^{71}$ In light of this, Part VII of the decree authorizes the court to modify the decree to further the enforcement of its goals. ${ }^{72}$ Since entry of the consent decree, the D.C. District Court has ruled on many issues regarding the relationship between AT\&T, the BOCs, and other telecommunications providers. ${ }^{73}$ Although the Justice Department has committed a great deal of resources to studying the effects of the decree and making recommendations

68 The question of whether this intention can be attributed to Congress is important because Chevron calls for a fictive yet plausible reconstruction of congressional intent. The implausibility of attributing this intention to Congress indicates that current law on this subject is out of line with Cheuron. See note 26.

${ }_{69}$ See United States v AT\&T, 552 F Supp 131 (D DC 1982).

70 Id at 140-43. See also Michael E. DeBow, Judicial Regulation of Industry: An Analysis of Antitrust Consent Decrees, 1987 U Chi Legal F 353, 364-65. Essentially, the decree separated the BOCs from AT\&T and allowed AT\&T to maintain its long-distance and equipment-manufacturing businesses, subject to equal-access restrictions. The decree also established "line of business" restrictions that prohibited the BOCs from entering into competition with AT\&T in certain areas including interexchange (long distance), manufacturing, information services, and several nontelecommunications lines of business. These restrictions may be lifted if BOCs show that activity within those areas will not impede competition or create dangers of monopoly. Id.

71 United States $v$ Western Electric, 900 F2d 283, 290 (DC Cir 1990) (triennial review of antitrust consent decree).

72 Id at 291.

73 DeBow, 1987 U Chi Legal F at 366. 
to the district court, ${ }^{74}$ it is the district court, subject to appellate review, that approves or disapproves waivers to or changes in the decree. ${ }^{75}$

Thus, as the D.C. Circuit noted in United States $v$ Western Electric Co., although government policy positions, as articulated by the FCC and the Justice Department, have changed with administrations, the court has been free to accept or reject these positions as it sees fit. ${ }^{76}$ In rejecting the petitions for BOC entry into certain lines of business, the district court has relied on its own view of what best promotes antitrust policy, rejecting the Justice Department's recommendations. ${ }^{77}$ In essence, a federal court, not responsible to any constituency and with no congressional mandate or relevant expertise, regulates the telecommunications industry through a consent decree. ${ }^{78}$

Although the AT\&T decree is unusual in its scope, Western Electric is an instructive example of the amount and type of policy-making discretion that consent decrees can confer on courts. ${ }^{79}$ Subsequent cases confirm the troubling fact that, in interpreting regulatory consent decrees, courts are making policy decisions that may not properly belong to the judiciary. ${ }^{80}$ At the very least, it is unclear whether Congress intended the courts to exercise this much discretion over regulatory policy.

Courts and commentators share this uneasiness over a policy-making judiciary. ${ }^{81}$ As the D.C. Circuit explained in West-

74 Id.

${ }^{75}$ United States $v$ Western Electric, 969 F2d 1231, 1235 \& n 6 (DC Cir 1992).

76900 F2d at 298.

77 Decisions to reject the Justice Department's recommendations have been based largely upon one judge's, the Honorable Harold H. Greene's, interpretation of the procompetition and antimonopoly requirements of the decree, as well as his views on which policies will best encourage competition. Id at 297-98. After noting recent changes in scholarly views on antitrust policy, the D.C. Circuit stated:

[W]e recognize that the DOJ may change its views-to incorporate different policy concerns-over time. That is not to say that we do not have any sympathy for the district court's attitude toward the DOJ's position changes in this Triennial Review. ... With little warning the DOJ completely altered its stance and is now generally hostile toward the [line-of-business] restrictions.

Id at 298. The D.C. Circuit recognized the distinct policy issues involved in interpreting the consent decree and upheld the district court judge's authority to reject the Justice Department's recommendations on the line-of-business restrictions. Id.

${ }_{78}$ DeBow, $1987 \mathrm{U}$ Chi Legal F at 365-66 (cited in note 70).

79 See also Adams v Bell, 711 F2d 161, 162-63 (DC Cir 1983) (noting that since a 1973 consent decree was entered, the D.C. District Court has taken an active role in delineating the Department of Education's responsibilities in enforcing Title VI of the Civil Rights Act).

so See text accompanying notes 85-96.

81 See DeBow, 1987 U Chi Legal F at 366 (cited in note 70); Browning-Ferris Indus- 
ern Electric, the Justice Department has primary enforcement authority for the Sherman Antitrust Act. ${ }^{82}$ Although the court found no doctrinal or statutory reason for deference, it recognized the importance of agency input and suggested that the district court "seriously consider the Department's economic analysis and predictions of market behavior" when interpreting the consent decree. ${ }^{83}$ This quotation expresses the obvious tension between the theory of contract-based interpretation of consent decrees and the reality that a court with no expertise, constituency, or statutory authority may ultimately set regulatory policy. ${ }^{84}$

2. Ambiguities in consent decrees: Opportunities for judicial policy-making.

Consent decrees that are ambiguous or silent on issues that arise subsequent to entry of the decree pose significant problems for courts. Reconstructing the bargain often provides little guidance and results in poor policy choices. The difficulty of balancing all the competing interests present in an administrative consent decree and the confused state of consent decree jurisprudence has led courts to apply the contract model inconsistently. In spite of their efforts, courts' good-faith attempts to reconstruct the parties' intent do not eradicate the central problem with the backward-looking approach of the contract-based model. Most often what is needed is a forward-looking policy decision-the type of decision that agencies are better situated to make.

For example, in United States $v$ Louisville and Jefferson County Metropolitan Sewer District, EPA discovered that a plant of the Metropolitan Sewer District ("MSD") was in violation of its permit requirements. ${ }^{85}$ As a result of these violations, MSD

tries $v$ Muszynksi, 899 F2d 151, 163-64 (2d Cir 1990).

$82900 \mathrm{~F} 2 \mathrm{~d}$ at 297.

83 Id. See also Broadcast Music, Inc. v Columbia Broadcasting System, Inc., 441 US 1, 16 (1979) (cautioning against disregarding the Justice Department's interpretation of antitrust law).

\&4 In response to this tension, Senator Robert Dole introduced a bill to put federal regulatory authority of the telecommunications industry in the hands of the FCC. Federal Telecommunications Policy Act of 1986, S 2565, 99th Cong, 2d Sess (June 16, 1986), in 132 Cong Rec S7742 (June 18, 1986). The FCC would then be required to promulgate a set of regulations that mirrored those in the AT\&T consent decree, thereby allowing the parties to make motions to vacate the decree on the grounds that a new regulatory authority made the continued existence of the decree unnecessary. Although the bill was never enacted, it indicates dissatisfaction with courts exercising this much regulatory authority. For a discussion of the bill, see DeBow, 1987 U Chi Legal F at 366 (cited in note 70).

${ }^{85} 983$ F2d 1070 (table), 1993 US App LEXIS 855, *2 (6th Cir). 
faced civil penalties of $\$ 10,000$ per day. ${ }^{86}$ EPA filed an enforcement action against MSD and over the next two years negotiated a consent decree whereby MSD would take several steps to bring its plant into compliance. ${ }^{87}$ In return for these measures, EPA agreed not to pursue stipulated penalties so long as MSD continued to make substantial efforts to comply with the appropriate effluent standards. ${ }^{88}$

Subsequent litigation between EPA and MSD focused on whether the purposes of the decree had been fulfilled when MSD had come into compliance with its permit. ${ }^{89}$ EPA believed that the purposes of the decree would be fulfilled immediately upon compliance with the effluent levels established in MSD's permit. MSD argued that the decree should not end until all work specified in the decree had been carried out in order to keep the plant in compliance given foreseeable increases in sewage flow. The decree was silent on this question. ${ }^{90}$

Although the court ultimately held for EPA, its backwardlooking attempt to reconstruct the agreement is strained and unprincipled..$^{91}$ The problem was that reconstructing the agreement provided no answer to the question being litigated. Both sides had good arguments for why, ex ante, they would not have agreed to the other side's position. EPA, however, had compelling policy reasons for rejecting MSD's interpretation: the efficient enforcement of the Clean Water Act may have been at stake. ${ }^{92}$

86 Id, citing 33 USC $\$ 1319(d)$ (1988).

B7 1993 US App LEXIS 855 at *2-3. MSD would first conduct an "Interim Corrective Action Program" to ascertain if minor improvements could bring the plant into compliance and an "Evaluation Program" to determine the feasibility and efficiency of alternative improvements. If these studies showed that MSD could not bring its plant into compliance without major modifications, then MSD would submit a "Final Plan and Schedule" detailing the necessary changes and equipment needed. This plan would then be submitted to the EPA and carried out if approved. Id.

88 Id at $* 3-4$.

89 Id at $* 11-12$.

90 Id at $* 2-4$.

91 Indeed, in a strongly worded dissent, Chief Judge Merritt accused the majority of failing to properly divine the parties' intent, offering his own plausible reading of the agreement. Id at $* 18-19$.

92 The decree gave protection to MSD for daily violations of permit levels. MSD wanted to remain under this protection while it made improvements in its facility to process greater levels of effluent. It argued that the decree made little sense if its requirements would be lifted the moment that the MSD plant achieved compliance with its permits. Theoretically MSD could fall out of compliance the next day and EPA would be forced to bring an additional enforcement action. EPA disagreed with this, stating that allowing the plant to make improvements for new customers while it was under the protection of the decree was unfair to other competitors and would set a bad precedent for dealing with other plants operating under consent decrees. Id at $* 11-13, * 19$. 
This problem is not limited to a single context. In one AT\&T case, the D.C. District Court read the term "manufacturer" as it pertained to line-of-business restrictions on the BOCs as excluding the BOCs from the design and development business. ${ }^{93}$ The language of the agreement was, however, inconclusive. With little evidence as to what the parties meant by "manufacture," the court turned to the purpose of the agreement and held that allowing the BOCs to participate in design and development was, on balance, more dangerous to competition than keeping them out. ${ }^{94}$ Although the court made a good-faith effort to reconstruct the agreement, it essentially made a policy judgment that had little to do with what the parties agreed to or what the language evinced. In this case, as in others, reconstructing the agreement did not provide an answer to the question. ${ }^{95}$

Cases like these illustrate the problems inherent in interpreting regulatory consent decrees. Often an appeal to the language or context surrounding the agreement is only a stab in the dark. When this is the case, a court will be forced to adopt what it believes to be a sensible reading in light of the statutory landscape. These interpretive scenarios create a great deal of uncertainty, making it difficult for both the regulators and the reg-

${ }_{93}$ United States $v$ Western Electric Co., 675 F Supp 655 (D DC 1987).

${ }^{94}$ United States $v$ Western Electric Co., 894 F2d 1387, 1391 (DC Cir 1990).

${ }^{95}$ See also United States $v$ Motor Vehicle Manufacturers Ass'n, 643 F2d 644 (9th Cir 1981). In that case, the government sought an extension of an antitrust consent decree that promoted competition between automobile manufacturers producing air pollution control devices. Id at 647. The decree was to last only ten years but allowed the government to petition the court for an extension. Id at 646 . However, the decree was completely silent on what factors the court should consider in granting or denying an extension. Id at 651. At first, the district court granted the government's petition, reading the decree's language as giving the government a unilateral right to an extension. Id at 646-47. Soon after, however, the district court entered a memorandum reversing its earlier decision, holding that, due to a changed regulatory climate, the decree was no longer warranted. Id at 647 . The Ninth Circuit overturned the district court's decision and remanded for a proper reconstruction of the parties' agreement. Admitting that the consent decree was silent on the issue, the Ninth Circuit held that the District Court had not properly reconstructed the agreement and should decide the extension issue "against a backdrop of findings which include the parties' reasonable expectations and understandings $[$,$] ... the$ statutory framework under which the government originally brought the action, and a balancing of the equities in light of the aforementioned considerations." Id at 651-52. Ultimately, there is no way to answer the question of extending the decree without evaluating its policy rationales. Here the government felt that the expiration of the decree would be fatal to competition in the air pollution control equipment market. Id at 648 . Whether a court could prove or disprove the government's position is largely irrelevant. The petition for an extension may best be understood as a policy view about what is required to continue to protect competition in the air pollution control area-an area that the then-current Administration obviously felt was very important. 
ulated to predict judicial decisions on the basis of regulatory policies.

It is important to note that a consent decree is itself an expression of policy. Although a court's authority to enter and enforce the decree comes from the agreement, the agency's authority to offer and accept a consent decree settlement in the first place comes from Congress. Thus, as in Chevron, one must try to reconstruct plausible congressional intent in granting the statutory authority to settle litigation through consent decrees. When Congress gave agencies this authority, it most likely did not intend to give significant policy-making authority to courts. Yet for the contract theory of interpreting regulatory consent decrees to make any sense, one must believe that Congress wanted agencies to be able to delegate a significant portion of their policymaking discretion to a court by making an agreement with a private party. In fact, Chevron seems to have made such a conception of congressional intent untenable in the absence of clear language to that effect. It is much more plausible to argue that Congress, in giving agencies the authority to settle litigation by decree, intended for agencies to retain this discretion. ${ }^{96}$

${ }_{96}$ One recent case endorsed a similar view with regard to administrative consent orders, agreements between an agency and a party that settle administrative rather than judicial disputes. See Browning-Ferris Industries v Muszynski, 899 F2d 151 (2d Cir 1990). In that case, the Second Circuit faced an administrative consent order, agreed to by both Browning and EPA, involving a site cleanup under $\$ 7003$ of the Resource Conservation and Recovery Act ("RCRA"), 42 USC $\$ 6973$ (1988). The RCRA Consent Order included a program requiring monitoring wells, but failed to specify what type of material was required to be used in the wells. $899 \mathrm{~F} 2 \mathrm{~d}$ at 152 . As the court noted,

[0]n the merits this case presents a narrow issue: can the EPA exercise its discretion pursuant to its expertise in environmental matters to require the installation of stainless steel rather than PVC wells to monitor ground water pollution, when the parties have voluntarily agreed that wells of some kind are required but have not specified the type of material?

Id at 160.

The court accorded the consent order little weight, properly recognizing that a reconstruction of the agreement would be of little help. The court also noted that Congress has delegated to EPA the responsibility for the cleanup of hundreds of landfills and hazardous waste sites throughout the country and concluded that:

[t]he judicial system lacks the resources and the expertise to address every scientific dispute that might arise from EPA's actions. The monitoring process chosen by EPA in this instance is within the normal discretion of an administrative agency interpreting a voluntary agreement-the RCRA Order.

Id at 163-64. The court's holding demonstrates an understanding that the order's silence should not automatically put the court into the position of policymaker, a position outside its normal adjudicative role. 


\section{RePlacing the CONTRACT MODEL WITH CHEVRON}

The primary difficulty in consent decree cases is that courts are trying to fit modern administrative exigencies into traditional contract models. Applying contract principles to regulatory consent decrees provides little guidance to courts and litigants and results in ineffective regulation..$^{97}$ Chevron provides a framework to correct this problem. It makes little sense to hold that agencies are competent to interpret their own statutes but not consent decrees enacted to enforce those same laws.

\section{A. The Stylized Chevron Test}

This Comment proposes that courts use a stylized Chevron analysis to interpret regulatory consent decrees. Under this test, the court must first determine whether the agency interpretation is outside the plain meaning of the agreement. If it is, then the plain meaning of the agreement should govern. If it is not, then the court should uphold the agency interpretation as a policy judgment so long as it is not arbitrary, capricious, or manifestly contrary to the agreement or statute at issue. This deferential standard will put policy-making back into the hands of the agency and reestablish the proper role of courts as checks on agency action. $^{98}$

\section{Step one: In the face of clear language.}

Because the consent decree itself is properly understood as an expression of policy, the court must try to be faithful to the language of that expression. If the language is clear, then the agency should be held to that expression of policy unless significant changes in the regulatory environment have occurred. ${ }^{99}$ As commentators have noted in the Chevron context, this first step is not toothless because very often the language of the agreement

97 This is especially true when the contract model at issue is so completely malleable. See text accompanying notes $42-60$.

${ }_{98}$ This policy-making realignment relies on a reading of Chevron that allows courts to make plausible yet fictive assumptions about congressional intent in the light of arguments about which body (the agency or the court) is best situated to make a particular determination. See note 26. Applying a Chevron-style analysis will have the additional advantage of allowing agencies to "update" decrees that have become obsolete. See DeBow, $1987 \mathrm{U}$ Chi Legal F at 357-62 (cited in note 70) (discussing the problem of obsolescence).

99 Changed circumstances is the current standard for altering a consent decree, even over the protest of a party to the decree. See Firefighters $v$ Cleveland 478 US 501, 527-28 (1985). 
at issue is precise. ${ }^{100} \mathrm{~A}$ firm adherence to the plain language of a consent decree will strike the proper balance between allowing for agency discretion and holding the agency to the clearly articulated expectations of the parties to the agreement. This plainlanguage test should resolve those cases in which the meaning of the decree is obvious on its face and the agency is advocating a purely post hoc reinterpretation of its original bargain. ${ }^{101}$

\section{Step two: Arbitrary-and-capricious review.}

The review for arbitrariness should closely mirror arbitraryand-capricious review under Cheuron, largely based on the standard articulated in the Administrative Procedure Act. ${ }^{102}$ As in the Cheuron context, agency interpretations will not always pass this test. ${ }^{103}$ Arbitrary-and-capricious review would give the agency wide latitude to make policy decisions but would not allow unbridled discretion; if the agency interpretation is so unreasonable as to be outside its authority under the agreement or statute, it will be rejected. Accordingly, this inquiry would require the agency to provide a detailed explanation of its interpretation and the factors that went into its policy decision. The factors must be relevant to the underlying statute, and the explanation must be reasonable. This test will ensure that the agency has drawn a rational conclusion after examining the relevant information. ${ }^{104}$

${ }^{100}$ See Starr, 3 Yale J Reg at 298 (cited in note 2) ("Despite its strengthening of the deference principle, however, Cheuron has not made judicial review a dead letter. On the contrary, as the Court's own post-Chevron decisions demonstrate, application of the Chevron framework-particularly in its first step-continues to be a potent check on agency interpretations."); Scalia, 1989 Duke L J at 520-21 (cited in note 26); Sunstein, 90 Colum $L$ Rev at 2091-92 (cited in note 4).

${ }^{101}$ This should allay many of the fears articulated in both the Stewart dissent in Continental Baking, 420 US at 249, and the Merritt dissent in Louisville and Jefferson County Metro Sewer District, 1993 US App LEXIS 855 at $* 17-19$.

${ }^{102}$ For an articulation of the standard of review under the Administrative Procedure Act, see Motor Vehicle Manufacturers Ass'n v State Farm Mutual Automobile Insurance Co., 463 US 29, 43 (1983). For the Chevron standard, see Silberman, 58 Geo Wash L Rev at 827-28 (cited in note 4 ).

${ }_{103}$ See Associated Gas Distributors v Federal Energy Regulatory Comm'n, 893 F2d $349,359,361$ (DC Cir 1989) (using the arbitrary-and-capricious standard to overturn agency interpretations); National Fuel Gas Supply Corp. v Federal Energy Regulatory Comm'n, 811 F2d 1563, 1572 (DC Cir 1987) (asserting that Chevron does not require abdication on the part of the court, but merely deference). See also Sunstein, 90 Colum L Rev at 2105 (cited in note 4) (arguing that "some decisions will be reversed or remanded under this approach").

${ }^{104}$ In this way, the test will comport with what courts require whenever they review an agency's policy decisions. See State Farm, 463 US at 43 ('Normally, an agency rule 
This two-part test accords with the theory underlying Chevron on several levels. As the D.C. Circuit has pointed out, Chevron's force is not limited to questions of statutory interpretation. ${ }^{105}$ Certainly it seems implausible that Congress wanted agencies to delegate their discretion to courts through agreements with third parties. Even if private rights are implicated, a plausible reconstruction of congressional intent may counsel for deference in reviewing agency interpretations of regulatory consent decrees. ${ }^{106}$ Applying the principles of Chevron to this context makes sense because the agency's advantages in electoral accountability, expertise, and policy-making legitimacy apply equally to the interpretation of regulatory consent decrees.

\section{B. Arguments for Deference to Agency Interpretations of Regulatory Consent Decrees}

1. Savings in social costs.

Deference to agency interpretations of consent decrees will likely produce significant social benefits: more effective regulation, a decrease in litigation costs, and more accountable decision making. First and foremost, deference to agency interpretations will create more effective regulation. One by-product of applying contract principles to ambiguous consent decrees is an increase in private parties' ability to delay enforcement. Assuming that a decree protects a private party from the imposition of any penalties so long as it is in force, ${ }^{107}$ the party may litigate any and all ambiguous terms in the decree to avoid regulatory requirements. Deference to the agency's interpretation of the decree will forestall this delay tactic and thus increase enforcement of regulatory statutes. An example may clarify this point.

would be arbitrary and capricious if the agency has relied on factors which Congress has not intended it to consider, entirely failed to consider an important aspect of the problem, offered an explanation for its decision that runs counter to the evidence before the agency, or is so implausible that it could not be ascribed to a difference in view or the product of agency expertise."); Associated Gas Distributors, 893 F2d at 361 (applying State Farm to an agency interpretation of a settlement agreement). See also Starr, 3 Yale J Reg at 307 (cited in note 2).

${ }^{105}$ See generally text accompanying notes 27-41. See also Starr, 3 Yale J Reg at 30001 (cited in note 2).

${ }^{106}$ Starr, 3 Yale J Reg at 300-01 (cited in note 2).

107 See, for example, Louisville and Jefferson County Metro Sewer District, 1993 US App LEXIS 855 at *11-12; Harris $v$ City of Philadelphia, 1994 US App LEXIS 27241, *4-6 (3d Cir). 
Often a consent decree stipulates an ongoing relationship between the two parties, such as in the MSD case. ${ }^{108}$ If this is so, the decree may require extensive studies about possible alternatives to rectify a statutory violation. For example, in the MSD case, the decree might have stipulated that an independent third party conduct a study that, when substantially completed, would be used to determine whether ambient-water-quality standards required additional oxygenation of MSD's sewage discharge. Without specific language in the decree about who is to conduct the study, how it will be conducted, and in what time frame, MSD could litigate every one of these issues, thereby substantially delaying any action on their part. This would greatly hamper EPA's ability to enforce the Clean Water Act by both increasing delays and raising the cost of obtaining compliance. There is the added result that a court, perhaps wholly lacking in expertise and accountability, will decide these important technical issues. As the case discussions in Part II illustrate, this scenario is not uncommon, and it does not serve the public's interest in efficient regulation. A deference model will both better serve the regulatory interests of the public and decrease this type of litigation.

Second, deference will reduce litigation costs. Parties under a consent decree will be less apt to go to court if they know that a court will most likely find the agency's interpretation "reasonable." For example, if MSD knows that the agency's interpretation of the language concerning the oxygenation study is reasonable, then MSD will be unlikely to expend resources to put the question to a court. This will result in less litigation after the consent decree is entered. ${ }^{109}$

Additionally, because the arbitrary-and-capricious standard requires less costly court education, it will probably decrease the costs of litigation once in court. Under the contract model, courts with little knowledge of the regulatory landscape and the technical information involved must be educated before they can determine the proper circumstances or technical issues surrounding the formation of a consent decree. Under the deference standard, courts will not need such intimate knowledge of the regulatory system.

108 See text accompanying notes 85-92.

109 For another example of this possibility, see the discussion of the Browning case in note 96. If a similar issue arises again, Browning will probably not litigate it. After this case, Browning knows that reasonable agency judgments about what the "consent order" requires will receive deference, and therefore will not expend resources litigating that type of claim. 
There are two types of technical expertise that an agency may possess. The first can be understood as a comprehensive understanding of the general regulatory landscape. This includes statutory interactions as well as standard operating procedures among the different players within the regulated area. The second is knowledge of the nuts and bolts of the regulated area-the science, technology, and economics that an agency uses to formulate policies and make judgments. Both types of knowledge are specialized and require experience and training. At least one commentator, recognizing these problems, has argued that instead of expanding agency discretion, courts should become sufficiently educated to make these sorts of determinations. ${ }^{110}$

Educating courts, however, may be undesirable. First, educating courts is an extremely expensive undertaking. To educate judges on either regulatory or scientific concerns during a trial greatly increases the cost of litigation. ${ }^{111}$ Second, although judges are certainly capable of understanding overall industry practices or industry "science,"112 these practices and technologies change rapidly over time. ${ }^{113}$ Thus, judges must obtain, at substantial cost, the same education that administrators obtain incidental to the performance of their duties. Congress created administrative agencies to regulate certain sectors of society and staffed them with experts. It would be odd if courts were not allowed-as they often are not under the contract model of consent decree interpretation - to take advantage of agency knowledge and expertise. Although judges will need to know something about regulatory concerns to conduct arbitrary-and-capricious review, the knowledge needed is minimal. Therefore, the necessary knowledge would be cheaper to obtain than if the judges were required actually to make the policy decision themselves. ${ }^{114}$

${ }^{110}$ See Christopher F. Edley, Jr., Administrative Law: Rethinking Judicial Control of Bureaucracy 238-39 (Yale, 1990).

${ }^{111}$ See Note, Fighting Fire with Firefighters: A Proposal for Expert Judges at the Trial Level, 93 Colum L Rev 473, 482-83 (1993) (recognizing the expense inherent in educating judges in technical matters). See also Stephen Breyer, Reforming Regulation, 59 Tulane L Rev 4, 10-11 (1984) (recognizing the limits on the ability of parties to properly educate judges on technical matters).

${ }_{112}$ In this context, "science" refers to both the specialized knowledge of a particular area of administration and the technology of the industry under regulation.

113 See Western Electric, 900 F2d at 297-98.

11 See Baltimore Gas and Electric Co. v Natural Resources Defense Council, Inc., 462 US 87, 103 (1983); Browning-Ferris Industries v Muszynski, 899 F2d 151, 164 (2d Cir 1990); Department of Navy v Egan, 484 US 518, 529 (1988); Hahn v Gottlieb, 430 F2d 1243,1249 (1st $\mathrm{Cir}$ 1970). See also the discussion of the Browning case in note 96. It is far more difficult for a court to decide which type of monitoring well is intended by a consent 
Finally, deference will result in better decision making because agencies have more expertise and greater electoral accountability. Evidence suggests that courts are relatively more likely to make mistakes-whether from failing to fully appreciate the complexity of the regulatory landscape, or misinterpreting scientific data-in choosing policy. As one commentator explains, there are numerous problems in drawing any kind of conclusive answers from data. ${ }^{115}$ These interpretative problems are exacerbated in the consent decree context when the decision maker is not well versed in regulatory minutia. For example, in many instances the evidence is not sufficient to provide a reliable answer; however, determining when this is the case requires a great deal of specialized knowledge. ${ }^{116}$ Furthermore, even if data is adequate, experts often differ on what the data means. ${ }^{117}$ Questions of methodology will often control how far a particular expert will extend the conclusions. Perhaps most importantly, experts differ over the inferences to draw from the data. ${ }^{118}$ Here the disparity between different experts is the widest. It may make little sense to rely on judges to make decisions between competing expert judgments given the likelihood that they will make less-informed choices. ${ }^{119}$

Judges may also choose poorly in a democratic sense. Given that certain answers may not be "right" or "wrong" in an objective sense, judges who are not responsible to the populace may choose against the will of the people. This was a central concern in Chevron. ${ }^{120}$ Where policy issues are concerned, it is better to have an agency with relatively more expertise and greater electoral ties make those decisions. The fact that agencies have a comparative advantage in determining the effects of a given policy over time, both objectively and democratically, counsels for court deference to agency interpretations of consent decrees.

agreement than whether a particular type of well is acceptable or reasonable.

115 Thomas O. McGarity, Substantive and Procedural Discretion in Administrative Resolution of Science Policy Questions: Regulating Carcinogens in EPA and OSHA, 67 Georgetown L J 729, 734 (1979).

116 Id at 736-37.

117 Id at 740. This is illustrated by the problem of competing expert witnesses in court actions. Often, demeanor and presentation will make more of a difference on a decision than the information presented.

118 Id at 743.

119 Although some judges have become well educated in the antitrust and labor contexts, others have recognized their relative lack of expertise in other areas. See Baltimore Gas, 462 US at 103; Browning, 899 F2d at 164; Egan, 484 US at 529; Hahn, 430 F2d at 1249.

120467 US at 866. 


\section{No more regulatory consent decrees?}

Perhaps the most important concern that arises from this proposal is whether deference to agency interpretations of consent decrees would significantly decrease incentives to enter into consent decree agreements. If an agency is allowed to reinterpret the bargain at will, critics argue, then parties will be reluctant to enter into the agreement, and overall litigation will increase. ${ }^{121}$ Although this argument makes some intuitive sense, it ignores the reality of many regulatory situations and fails to recognize the other advantages in decreased litigation and decreased litigation costs that counsel in favor of deference. ${ }^{122}$

First, agencies should be willing to adjust their settlement offers in order to make them more attractive to parties concerned about the effects of unforeseen or changed circumstances. Even if the terms of the decrees tended to be less favorable for the agencies, it would still be in their interests to settle their disputes with consent decrees. ${ }^{123}$ Given the probability of an adverse court ruling, higher penalties imposed by a court, and less flexibility in both time frame and solution, private parties should also be willing to enter into adequately adjusted consent decrees.

121 Percival, $1987 \mathrm{U}$ Chi Legal F at 344 (cited in note 64). Note that very little empirical evidence exists concerning the advantages of settlement through consent decree. See generally Judith Resnik, Judging Consent, 1987 U Chi Legal F 43, 67-85. Commentators have made several claims about the general benefits of consent decrees. First, they argue that consent decrees shorten costly and time-consuming litigation, freeing agency resources for other uses. Second, consent decrees allow for more closely tailored solutions than a court could provide. Third, consent decrees create more effective and "cheaper" enforcement due to continued court oversight, and thus create more effective regulation. See generally Frank H. Easterbrook, Justice and Contract in Consent Judgments, 1987 U Chi Legal F 19, 25; Mengler, 29 BC L Rev at 314, 328, 331 (cited in note 5); Note, United States v. Fisher: "Posner's Dilemma" and the Uncertain Triumph of Outcome Over Process, 21 Envir L 427, 434-35 (1991); Percival, $1987 \mathrm{U}$ Chi Legal F at 334 (cited in note 64); Firefighters $v$ Cleveland, 478 US 501, 523-24 n 13 (1985). Although these arguments have intuitive appeal, others have argued persuasively that consent decrees do not necessarily decrease the incidence or costs of litigation nor increase the effectiveness of regulation. See generally Kramer, 87 Mich L Rev at 327-28 (cited in note 5); Owen M. Fiss, Justice Chicago Style, 1987 U Chi Legal F 1; Resnik, 1987 U Chi Legal F 43. For discussions concerning the problems of settlement generally, see Owen M. Fiss, Against Settlement, 93 Yale L J 1073 (1984); Charles Silver, Justice in Settlements, Soc Phil \& Policy 102 (Autumn 1986).

122 See text accompanying notes 109-14.

${ }^{123}$ See Easterbrook, 1987 U Chi Legal F at 25 ("Still, if the SEC catches Ivan Boesky in the act, a settlement and consent decree can make both better off: both avoid the protracted litigation that would eat up much of the $\$ 100$ million stake; the SEC obtains a pile of money it can distribute, and it frees up its legal staff for other work. The consensual disposition both enforces the legal rule and leaves benefits for the parties to share."). 
This possibility is increased in the regulatory setting by the fact that there is often better information about possible settlement ranges. For example, consider that many regulatory statutes are strict liability laws. ${ }^{124}$ Given their limited resources, administrative agencies rarely file enforcement proceedings unless they have ample evidence of statutory violations. ${ }^{125}$ Thus defendants do not face a normal guilt-or-innocence paradigm. ${ }^{126}$ The question is often not whether they will have to pay but how much. Given that both the agencies and the violators are fully aware of the affirmative defenses and penalties for violations, agencies can usually make offers that are superior to what the violating parties could expect from a court. ${ }^{127}$

Second, both the language of the agreement and the arbitrary-and-capricious standard will serve to protect the interests of defendants in these cases. As the D.C. Circuit has observed in the contract setting, deference to agency interpretations may make the agreements more explicit. ${ }^{128}$ Although this may increase the costs of bargaining, subsequent savings in litigation costs may be greater. As Judge Robert Bork has noted: "Indeed, if judicial deference to the Commission forces greater clarity in settlement agreements, with less subsequent litigation, efficiency will be increased for private parties as well as for the regulatory system."129 This systemic effect has been discussed in the Chevron context as well: if the primary method that Congress has to cabin agency discretion is statutory language, that lan-

124 See Lynda J. Oswald, Strict Liability of Individuals Under CERCLA: A Normative Analysis, 20 BC Envir Aff L Rev 579, 598-99 (1993) (indicating the strict liability of the Clean Water Act and CERCLA). See also United States $v$ Northeastern Pharmaceutical \& Chemical Co., 810 F2d 726, 743-45 (8th Cir 1986) (noting that both RCRA and CERCLA impose strict liability).

${ }_{125}$ Richard A. Posner, Economic Analysis of Law 603 (Little, Brown, 4th ed 1992).

${ }^{126}$ Over 70 percent of antitrust cases are settled by consent decree, and once an enforcement action is brought, it is generally the defendant who initiates negotiation. This indicates that the party alleged to be in violation of the statute recognizes that he or she will probably get a better deal from the Justice Department than from a trial court. See generally DeBow, 1987 U Chi Legal F at 353-54 (cited in note 70).

127 For a general discussion of how settlements are calculated, see William M. Landes, An Economic Analysis of the Courts, 14 J L \& Econ 61 (1971).

${ }^{128}$ National Fuel Gas Supply Corp. v Federal Energy Regulatory Comm'n, 811 F2d 1563, 1572 n 5 (DC Cir 1987).

${ }^{129}$ Id. This problem is very real. There is currently a great deal of ongoing litigation precipitated by intentionally ambiguous consent decrees. Typically a party will lobby for an ambiguous provision to allow "foot-dragging" later. More precise drafting of consent decrees and the certainty that comes from a policy of agency deference could forestall a great deal of this litigation. See Mengler, $29 \mathrm{BC} \mathrm{L} \mathrm{Rev} \mathrm{at} 329$ (cited in note 5). 
guage may become more exact. ${ }^{130}$ There, as here, the costs of clarity may be offset by fewer costly controversies.

The arbitrary-and-capricious standard will also offer some protection for the parties' expectations. As formulated by the Court in Motor Vehicle Manufacturers Ass'n v State Farm Mutual Automobile Insurance Co., the arbitrary-and-capricious standard requires submission of a detailed explanation of the agency decision along with the factors considered. ${ }^{131}$ If the factors considered are not relevant to the statute at issue, ${ }^{132}$ if the agency failed to consider an important aspect of the problem, or if its offered explanation runs counter to the evidence or is so implausible that it could not be ascribed to a difference in view or the product of agency expertise, then the interpretation will not be allowed to stand. ${ }^{133}$

Parties will adapt to the new paradigm by making agreements more explicit and relying on courts to police the outer boundaries of allowable policy discretion. It is impossible for parties entering into consent decrees to avoid unforeseen contingencies. Under the contract model currently in place, courts are making policy decisions. Although agencies and private parties may win and lose in equal numbers, this paradigm has significant costs and violates principles of political accountability. Even if the total number of consent decree settlements were to decline, the advantages of deference outweigh this loss.

\section{CONCLUSION}

The Chevron revolution should include deference to agency interpretations of regulatory consent decrees. The contract model has proved inadequate because it ignores the agencies' policy interests in the efficient enforcement of our public laws. The institutional advantages that agencies have in greater expertise, policy-making legitimacy, and electoral accountability all counsel

130 See Starr, 3 Yale J Reg at 311 (cited in note 2) ("Chevron also places the burden on Congress to legislate with greater precision if it wants to temper the agencies' new power.").

131463 US 29, 43 (1983).

1s2 See, for example, Western Electric, 900 F2d at 299-300.

133 National Fuel, 811 F2d at 1572. See also Consolidated Gas Supply Corp. v Federal Energy Regulatory Comm'n, 745 F2d 281, 291 (4th Cir 1984). In the Cheoron context, several commentators have noted that this standard will still result in some decisions against agencies. See Sunstein, 90 Colum L Rev at 2105 (cited in note 4), citing Associated Gas Distributors v Federal Energy Regulatory Comm'n, 893 F2d 349, 359 (DC Cir 1989). See also Silberman, 58 Geo Wash L Rev at 827 (cited in note 4). 
for this extension of Chevron. It does not make sense, in attempting to divine congressional intent, to assume that Congress intended agencies to delegate significant policy-making discretion to courts by entering into consent decrees with third parties.

In addition, a great deal of confusion and unnecessary litigation will be eradicated if courts defer to agencies in interpreting the ambiguities within consent decrees. Under the standard that this Comment proposes, deference will be limited by a Cheuron "plain meaning" and "arbitrary-and-capricious" review. This standard will afford meaningful review without unnecessarily hindering the regulatory process. It is superior to contract analysis, which does not adequately take into account the forward-looking policy elements involved in consent decree interpretation. Courts are at a comparative disadvantage, both democratically and in relative expertise, to adjudicate adequately what are fundamentally policy decisions. 